\title{
APLIKASI M-LEARNING SEBAGAI MEDIA PEMBELAJARAN CONVERSATION PADA HOMEY ENGLISH
}

\author{
${ }^{1 *}$ Syaiful Ahdan, ${ }^{2}$ Andini Reska Putri, ${ }^{3}$ Adi Sucipto \\ ${ }^{1,3}$ Teknologi Informasi, Fakultas Teknik dan Ilmu Komputer, Universitas Teknokrat Indonesia \\ ${ }^{2}$ Sistem Informasi, Fakultas Teknik dan Ilmu Komputer, Universitas Teknokrat Indonesia, \\ Jl. Zainal Abidin. Pagaralam No.9-11, Kedaton,Bandar Lampung, Lampung 35132, Indonesia \\ Email: syaifulahdan@teknokrat.ac.id,andinireskaputri15@gmail.com,adi.sucipto@teknokrat.ac.id
}

(Diterima: 4 Juni 2020 ,direvisi: 24 Juli 2020, disetujui: 21 Agustus 2020)

\begin{abstract}
Learning media is one component that includes teaching materials and equipment that can support the learning process, it has an impact on the development of learning technology that continues to increase in various forms. one function of learning media is to present messages and information clearly, so that it can facilitate and improve the process and learning outcomes, In this study the authors propose an online-based learning system that can overcome problems associated with the learning process at one of the English language courses in Bandarlampung, specifically for conversation learning. The contribution in this research is to make online learning media based on mobile applications that can help the learning process without going through face-to-face. This application is built on the android platform with system modeling using the Unified Modeling Language (UML), the system that has been built is then tested using ISO 9126 to obtain results: in the aspect of functionality (admin) 92.7\%, functionality (students) $93.95 \%$ and in the aspect of usability (admin) 96.25\%, usability (students) 93.85\%.
\end{abstract}

Keywords: e-learning, m-learning, online conversation learning

\begin{abstract}
ABSTRAK
Media pembelajaran adalah salah satu komponen yang mencakup bahan ajar dan peralatan yang dapat mendukung proses pembelajaran, perkembangan teknologi terus mengalami kemajuan yang pesat, hal ini berdampak pada perkembangan teknologi pembelajaran yang terus meningkat dalam berbagai bentuk. Fungsi media pembelajaran salah satunya adalah untuk menyajikan pesan dan informasi dengan jelas, sehingga dapat memudahkan dan meningkatkan proses dan hasil pembelajaran, media pembelajaran juga dapat meningkatkan perhatian siswa agar dapat meningkatkan motivasi belajar, keterbatasan ruang dan waktu menjadi faktor yang penyebap keterlambatan dalam proses pembelajaran, hal tersebut menyebabkan transfer bahan ajar tidak sampai kepada siswa. Penelitian ini mengusulkan desain dan pemodelan sistem pembelajaran berbasis daring yang dapat mengatasi masalah yang terkait dengan proses pembelajaran pada salah satu tempat kursus bahasa inggris di Bandarlampung, khususnya untuk pembelajaran percakapan. Kontribusi dalam penelitian ini adalah membuat media pembelajaran daring berbasis aplikasi mobile yang dapat membantu proses pembelajaran tanpa melalui tatap muka. Aplikasi ini dibangun pada platform android dengan pemodelan sistem menggunakan Unified Modeling Language (UML), sistem yang telah dibangun kemudian diuji menggunakan ISO 9126 dengan memperoleh hasil: pada aspek fungsi (admin) 92,7\%, aspek fungsi (siswa) 93,95\% dan pada aspek kegunaan (admin) 96,25\%, aspek kegunaan (siswa) $93,85 \%$.
\end{abstract}

Kata Kunci: e-learning, pembelajaran bergerak, pembelajaran percakapan daring

\section{PENDAHULUAN}

Saat ini penggunaan perangkat mobile menjadi suatu isu utama bagi para peneliti dan praktik pendidikan semenjak perangkat mobile telah digunakan secara luas di kalangan masyarakat, hal tersebut dikarenakan perangkat mobile terus berkembang seiring dengan kemampuan yang ditawarkan [1]. Aktifitas pembelajaran yang dilakukan oleh para guru saat ini telah memanfaatkan m-learning 
sebagai media dan metode pembelajaran, karena penggunaan perangkat mobile secara personal di nilai sangat sesuai dan praktis [1], [2]. M-learning akan memainkan peran yang semakin signifikan dalam pengembangan metode belajar mengajar untuk pendidikan tinggi. Namun, keberhasilan implementasi M-learning di pendidikan tinggi akan dipengaruhi pada pengguna terhadap teknologi ini [3]. M-learning mengacu pada proses penyampaian konten pembelajaran kepada siswa kapan saja dan di mana saja melalui jaringan internet nirkabel dan perangkat seluler, termasuk ponsel pintar, dan pemutar audio digital. Pengguna m-learning dapat berinteraksi dengan sumber daya pendidikan yang jauh dari tempat mereka yang biasa belajar di kelas atau komputer desktop [4]. m-learning mengacu pada penggunaan perangkat pembelajaran berbasis mobile seperti smartphone, asisten digital pribadi, PC tablet, laptop, dan komputer jinjing [5]. Media pembelajaran adalah salah satu variabel penting yang memungkinkan proses belajar mengajar dapat mencapai keberhasilan [6], Penggunaan Media dalam proses pengajaran dan pembelajaran bermaksud untuk memotivasi siswa, ditambah dengan penggunaan multimedia yang menarik akan menimbulkan kenyamanan dan kesenangan siswa dalam belajar, siswa akan lebih cenderung mempelajari topik baru dalam pembelajaran, Media pembelajaran berbasis teknologi dapat memberikan pengalaman belajar yang berbeda dibandingkan pembelajaran konvensional [7].

Latar belakang penelitian ini fokus pada proses kegiatan belajar yang diterapkan di homey english, pelaksanaan pelajaran conversation dilakukan dengan proses tatap muka belum dapat mengatasi masalah pada siswa yang tidak hadir sehingga proses penyampaian materi melalui bahan ajar tidak tersampaikan, oleh karena itu perlu solusi terhadap permasalahan siswa yang tidak dapat hadir dengan cara memberikan bahan ajar melalui penugasan dan ketersediaan bahan ajar yang dapat diakses langsung oleh siswa atau pembelajar sehingga dapat memudahkan proses pembelajaran tanpa harus bertatap muka di kelas. Selain itu, keterbatasan ruang dan waktu menjadi faktor yang penyebap keterlambatan dalam proses pembelajaran, hal tersebut menyebabkan transfer bahan ajar tidak sampai kepada siswa. Kontribusi dalam penelitian ini adalah membuat desain dan pemodelan sistem pembelajaran berbasis daring yang dapat mengatasi masalah-masalah yang terkait dengan proses pembelajaran pada salah satu lembaga kursus bahasa inggris di Bandarlampung, khususnya untuk pembelajaran conversation. Output pada penelitian ini adalah aplikasi pembelajaran daring berbasis mobile yang dapat membantu proses pembelajaran tanpa melalui tatap muka, selain itu bagaimana media pembelajaran yang dibangun dapat diterapkan tanpa mengurangi kualitas belajar seperti pada tatap muka.

Adapun batasan-batasan dalam penelitian ini adalah, media pembelajaran ini hanya digunakan untuk bidang pelajaran conversation, sistem yang dibangun dapat menampilkan informasi pelajaran, upload modul materi conversation, dan ketersediaan materi audio atau video, communication, dan tersedianya evaluasi pembelajaran conversation. Tujuan dari penelitian ini adalah membagun aplikasi M-learning sebagai media pembelajaran bahasa inggris untuk meningkatkan sistem pembelajaran kepada siswa homey english tanpa harus hadir di tempat kursus.

\section{TINJAUAN PUSTAKA}

Pada saat ini, tidak ada definisi pasti dari M-learning. jika istilah seperti jarak pendidikan merupakan indikasi, mungkin tidak akan ada definisi M-learning yang bertahan lama untuk waktu yang akan datang, Pada Januari 2005, Louris dan Eteokleous (2005) melaporkan menerima 1.240 item saat mencari Google untuk istilah + "definisi"; luar biasa, ketika mereka melakukan pencarian yang sama pada bulan Juni 2005, google menyediakan 22.700 item [8]. Mobile learning dapat didefinisikan sebagai penggunaan perangkat nirkabel dan portabel seperti ponsel, asisten digital pribadi, smartphone, personal computer, dan PC tablet yang bertujuan untuk mencapai fleksibilitas dan interaktivitas [9]. Mobile learning kadang-kadang disebut juga M-learning, adalah pembelajaran yang menggunakan perangkat portabel kecil. Perangkat komputasi kecil/portabel termasuk perangkat komputasi: smartphone, asisten digital pribadi (pda), dan perangkat genggam. M-learning adalah tahap baru dalam pengembangan e-learning dan pembelajaran jarak jauh. Ini mengacu pada pembelajaran apa pun yang terjadi melalui perangkat seluler nirkabel seperti ponsel pintar, PDA, dan PC tablet di mana perangkat ini dapat bergerak dengan peserta didik untuk memungkinkan pembelajaran kapan saja, di mana saja [3]. M-learning adalah lanskap pembelajaran baru yang menawarkan kesempatan untuk lingkungan belajar yang berpusat kolaboratif, pribadi, informal, dan 
siswa. Dalam menerapkan sistem pembelajaran apa pun seperti lingkungan pembelajaran seluler, penting untuk memahami tantangan yang memengaruhi implementasinya dalam budaya tertentu. Selain itu, harapan peserta didik dan instruktur dianggap perlu untuk dipertimbangkan [10].

pada lingkungan m-learning, ruang kelas adalah tempat guru menggunakan berbagai perangkat, baik yang dikeluarkan sekolah maupun milik siswa, untuk meningkatkan pembelajaran dan menciptakan perubahan filosofis dalam pengajaran, selain itu m-learning memiliki strategi pembelajaran yang berkonsentrasi pada pendekatan pembelajaran yang digunakan dengan penggunaan berbagai perangkat dan platform, m-learning telah digunakan dalam pendidikan tinggi dan pengaturan K-12 menawarkan beberapa keuntungan dan lingkungan, m-learning pada umumnya didefinisikan sebagai ruang kelas tempat siswa yang memiliki perangkat seluler diizinkan untuk terhubung ke Wi-Fi sekolah dan menggunakannya di kelas untuk meningkatkan pembelajaran mereka [11]. Beberapa penelitian membahas tentang mobile learning, Tabel 1 menyajikan beberapa studi tentang penelitian mobile learning tebaru dalam kurun waktu 5 tahun terakhir

Tabel 1. Studies On M-Learning

\begin{tabular}{|c|c|c|}
\hline Author & Title & Result \\
\hline $\begin{array}{l}\text { Hibrizi } \\
\text { zakwan }\end{array}$ & $\begin{array}{l}\text { Aplikasi Belajar Bahasa } \\
\text { Inggris }\end{array}$ & $\begin{array}{l}\text { Aplikasi yang dikembangkan oleh Hibrizi zakwan yang dapat } \\
\text { diunduh melalui playstore pada platform Android dengan nama } \\
\text { aplikasi "Belajar bahasa inggris offline Cepat", aplikasi ini } \\
\text { berfungsi sebagai pemandu pembalajaran untuk belajar bahasa } \\
\text { inggris yang memiliki beberapa fitur seperti : Grammar } \\
\text { Tenses, Part Of Speech, Kosakata, Audio English Lesson, } \\
\text { Grammer dan Conversation. Kelebihan aplikasi ini memiliki } \\
\text { fitur yang lengkap untuk ditawarkan kepada pengguna aplikasi, } \\
\text { sedangkan kekurangannya adalah, pada aplikasi ini tidak } \\
\text { memiliki pengelolaan user seperti guru dan siswa, sehingga } \\
\text { tidak ada admin yang dapat mengontrol fungsi fitur apa saja } \\
\text { yang dapat diakses oleh pengguna, Sedangkan kontribusi dari } \\
\text { aplikasi m-learning homey english selalin fitur yang dimiliki, } \\
\text { jika dilihat dari sisi pengguna, memiliki } 3 \text { aktor yang dapat } \\
\text { berperan pada aplikasi tersebut yaitu (Admin, Guru, dan Siswa) }\end{array}$ \\
\hline $\begin{array}{l}\text { R. } \\
\text { Alhajri. } \\
\text { (2016) }\end{array}$ & $\begin{array}{l}\text { Prospects and } \\
\text { Challenges of Mobile } \\
\text { Learning } \\
\text { Implementation: A Case } \\
\text { Study }\end{array}$ & $\begin{array}{l}\text { Studi menunjukkan bahwa sikap siswa dan instruktur terhadap } \\
\text { m-learning disambut baik, dan bahwa mayoritas siswa dan } \\
\text { instruktur percaya bahwa m-learning menarik karena } \\
\text { memungkinkan kebebasan untuk belajar kapan pun dan di } \\
\text { mana pun mereka mau terlepas dari jenis kelamin, usia mereka, } \\
\text { berdasarkan } 499 \text { respondent [10]. }\end{array}$ \\
\hline $\begin{array}{l}\text { T.H.Fitt } \\
\text { s.(2015) }\end{array}$ & $\begin{array}{l}\text { Teacher Implementation } \\
\text { Of Mobile Learning } \\
\text { Initiative At a Sixth } \\
\text { Grade School: a } \\
\text { Phenomenological } \\
\text { Study }\end{array}$ & $\begin{array}{l}\text { Temuan pada penelitian ini adalah tentang persepsi peserta } \\
\text { yang berhubungan dengan presetasi siswa dipengaruhi oleh } \\
\text { SES: Socio-Economic Levels and Student Achievement, dan } \\
\text { keahlian pada penggunaan teknologi, Siswa yang memiliki } \\
\text { SES lebih rendah memiliki pengalaman dengan teknologi lebih } \\
\text { sedikit. Dalam banyak kasus, sebagian besar siswa yang tingkat } \\
\text { pencapaian akademiknya dibawah } 25 \% \text { berasal dari rumah } \\
\text { dengan tingkat SES yang lebih rendah [11]. }\end{array}$ \\
\hline $\begin{array}{l}\text { V.I. } \\
\text { Toktaro } \\
\text { va. } \\
(2015)\end{array}$ & $\begin{array}{l}\text { Design and } \\
\text { Implementation of } \\
\text { Mobile Learning Tools } \\
\text { and Resources in the } \\
\text { Modern Educational } \\
\text { Environment of } \\
\text { University }\end{array}$ & $\begin{array}{l}\text { efektivitas sistem m-learning yang dirancang memberikan } \\
\text { kontribusi pada peningkatan pendidikan dan dukungan metodis } \\
\text { dari proses pendidikan keanekaragaman. Menurut penelitian, } \\
\text { sistem m-learning "Programming Aplikasi Mobile untuk } \\
\text { Android" telah diimplementasikan dalam proses pembelajaran } \\
\text { dan pengajaran mahasiswa dari Mari State University [12]. }\end{array}$ \\
\hline
\end{tabular}


Media dan teknologi pendidikan dapat didefinisikan sebagai semua alat komunikasi seperti cetakan, grafik, animasi, audio dan audio visual. Teknologi multimedia pendidikan menggabungkan semua kualitas cetak, grafik, animasi, audio dan audio visual dan teknologi didefinisikan sebagai objek atau proses yang berasal dari manusia yang dapat digunakan untuk menyampaikan media dan multimedia. Dalam hal ini, teknologi mencakup fenomena yang beragam seperti buku, film, televisi, dan internet. Dalam pendidikan, media adalah sistem simbol yang digunakan guru dan peserta didik dalam merepresentasikan pengetahuan dan teknologi adalah alat yang memungkinkan mereka untuk berbagi representasi pengetahuan mereka dengan orang lain [13]. Media atau alat peraga instruksional, dikenal sebagai salah satu alat dalam kegiatan pembelajaran. Dikatakan sebagai alat karena berfungsi sebagai alat untuk membantu guru dalam memperlancar jalur pengajaran, sehingga dapat memperjelas pemahaman siswa tentang materi yang dipelajari [14]. Media adalah sarana penyaluran pesan atau informasi pembelajaran untuk disampaikan oleh sumber pesan ke target atau penerima pesan. Media pembelajaran dapat digunakan oleh guru dalam kegiatan belajar mengajar [15]. Sistem pendidikan jarak jauh (Distance Education System), guru dan peserta didik secara fisik terpisah dan materi pengajaran disampaikan melalui sistem telekomunikasi. Aplikasi global DES telah terbukti sebagai pendekatan yang berhasil dan berguna dalam pendidikan [16]. Berdasarkan kemampuan teknologi, struktural, dan keuangan, sejumlah varietas teknologi diterapkan dalam sistem pembelajaran jarak jauh pendidikan tinggi seperti : media cetak, media audio, dan Media video digunakan untuk menyampaikan pesan dalam hal tujuan pendidikan khusus untuk menyampaikan dan menyebarluaskan materi pengajaran kepada pelajar. Berdasarkan karakteristik peserta didik dan beberapa faktor yang harus dipertimbangkan dalam pemilihan media berfokus pada tujuan dan metodologi sesuai dengan tabel yang dibutuhkan pada Tabel 2 berikut.

Tabel 2. Ketepatan Media Untuk Pembelajaran Jarak Jauh, [17]

\begin{tabular}{|c|c|c|c|c|}
\hline Media & Information & Producer & $\begin{array}{l}\text { Principles \& } \\
\text { Concept }\end{array}$ & $\begin{array}{l}\text { Attitudes \& } \\
\text { Values }\end{array}$ \\
\hline $\begin{array}{ll}\text { 1. } & \text { Audio } \\
\text { 2. } & \text { Audio Graphics } \\
\text { 3. } & \text { Two-way } \\
& \text { audio/one way } \\
& \text { audio } \\
\text { 4. } & \text { Two-way } \\
& \text { audio/two-way } \\
\text { video }\end{array}$ & $\begin{array}{l}\text { - } \text { Readliness } \\
\text { - } \text { Audio/videot } \\
\quad \text { ape } \\
\text { - } \text { Lecture } \\
\text { - Student } \\
\text { - Presentation } \\
\text { - } \text { Guest } \\
\quad \text { speaker }\end{array}$ & $\begin{array}{ll}\text { - } & \text { Demontstr } \\
& \text { ations } \\
\text { - } & \text { Lecture } \\
\text { - } & \text { Readliness }\end{array}$ & $\begin{array}{ll}\text { - } & \text { Class } \\
& \text { discussions } \\
\text { - } & \text { Peer teaching } \\
\text { - } & \text { case studies } \\
\text { - } & \text { Panel } \\
& \text { discussions } \\
\text { - } & \text { Group projects }\end{array}$ & 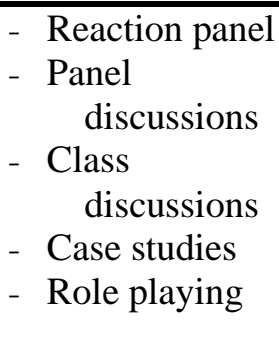 \\
\hline $\begin{array}{ll}\text { 5. } & \text { Computer } \\
& \text { Conferences }\end{array}$ & $\begin{array}{l}\text { - } \text { Readliness } \\
\text { - } \text { Guest } \\
\text { speaker }\end{array}$ & $\begin{array}{l}\text { - Readliness } \\
\text { - tutorials }\end{array}$ & 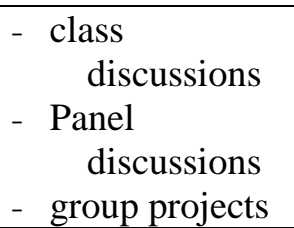 & 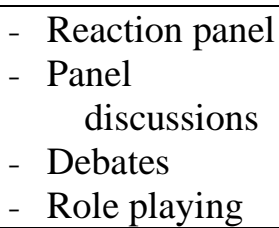 \\
\hline
\end{tabular}

Hasil penelitian menunjukan bahwa pengajaran dan pembelajaran berbasi teknologi lebih efektif jika dibandingkan dengan ruang kelas tradisional karena menggunakan peralatan TIK dapat menyiapkan lingkungan belajar lebih aktif dan menarik dan efektif bagi guru dan siswa, (Ghavifekr, S. \& Rosdy, W.A.W. (2015), Sebagian besar guru dalam penelitian ini setuju bahwa TIK membantu meningkatkan manajemen kelas karena siswa berprilaku baik dan lebih fokus, selain itu siswa belajar lebih efektif dengan penggunaan TIK karena pelajaran yang dirancang lebih menarik dan menarik, dengan demikian para peserta sepakat bahwa mengintegrasikan TIK dapat mendorong pembelajaran siswa. Android adalah arsitektur perangkat lunak open source populer yang disediakan oleh open handset alliance yang saat ini menargetkan perangkat seluler, seperti ponsel cerdas dan komputer tablet [18], [19]. Android adalah tumpukan perangkat lunak untuk perangkat seluler yang mencakup sistem operasi, middleware, dan aplikasi utama. Android SDK menyediakan alat dan API yang diperlukan untuk mengembangkan aplikasi pada platform android menggunakan bahasa pemrograman java [20], [21].

Berdasarkan tinjauan pustaka yang telah dilakukan pada penelitian terdahulu, bahwa kontribusi yang dilakukan oleh penulis terhadap penelitian ini adalah, membangun sebuah aplikasi pembelajaran 
bahasa inggris conversation berbasis android dengan fitur manajemen pengelolaan aplikasi berbasis web dan belum pernah dilakukan pada penelitian sebelumnya, aplikasi yang dikembangkan memiliki fitur pengelolaan user seperti hak akses guru dalam mengelola pembelajaran dan fitur yang dimiliki oleh siswa dalam melaksanakan pembelajaran online, pada panel admin, pengelola dapat mengontrol fungsi fitur apa saja yang dapat diakses oleh pengguna, aplikasi yang dikembangkan juga memiliki fitur evaluasi terhadap pembelajar.

\section{METODE PENELITIAN}

Bagian ini merupakan tahapan-tahapan yang dilakukan oleh peneliti terkait dengan seluruh aktifitas yang dilakukan dalam mengembangkan aplikasi m-learning seperti prosedur, data-data, dan desain perancangan sistem.

Tahapan penelitian pada dasarnya adalah tahapan-tahapan antara konsep-konsep yang ingin diamati atau diukur melalui penelitian yang akan dilakukan, Tahapan penelitian dapat dilihat pada (Gambar 1).

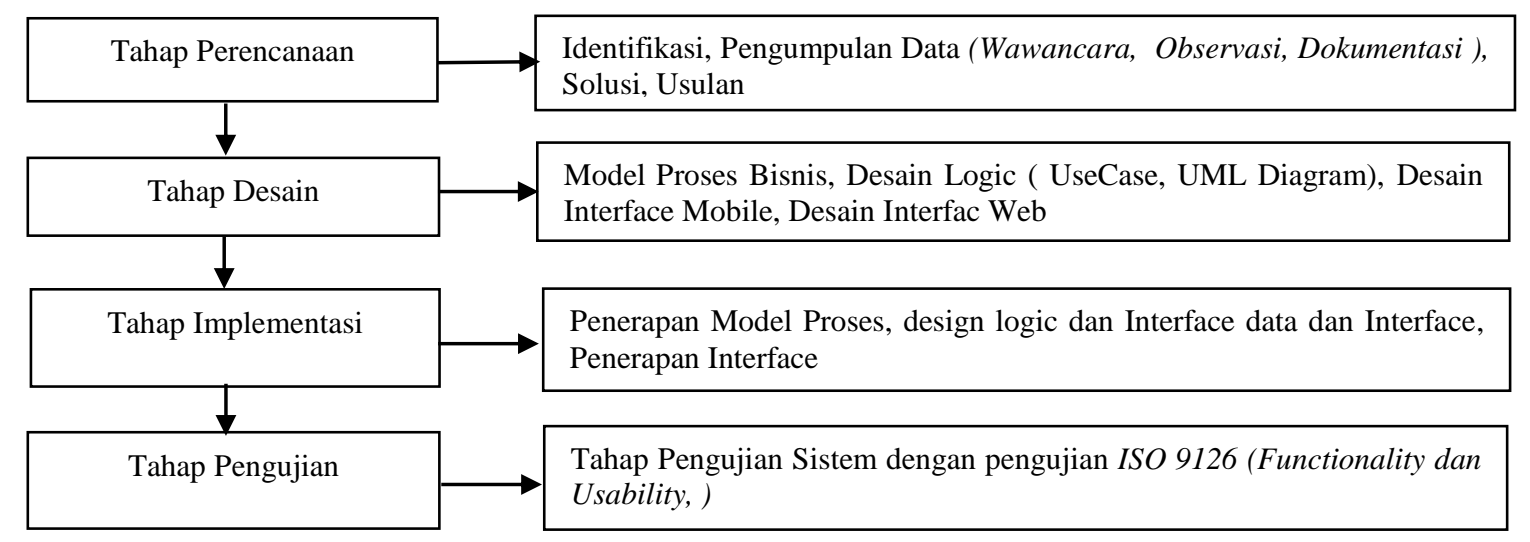

\section{Gambar 1. Tahapan Penelitian}

Pada tahapan desain bertujuan untuk mendesain model dari sistem informasi yang diusulkan dalam bentuk logical model yang menjelaskan bagaimana nantinya sistem secara fisik dapat diterapakan, pada tahapan ini terdiri dari (1) Pembuatan model proses bisnis, (2) Desain Logic (Usecase, UML Diagaram), (3) Desain Interface Mobile, (4) Desain Interface Web. Tahapan ini juga bertujuan suatu usulan yang sesuai dengan solusi yang telah ditetapkan pada tahap sebelumnya, usulan yang diajukan adalah membuat desain dan pemodelan sistem pembelajaran berbasis daring yang dapat mengatasi masalah-masalah yang terkait dengan proses pembelajaran pada salah satu lembaga kursus bahasa inggris di Bandarlampung berbasis android. Adapun usulan tersebut akan dijelaskan pada pembahasan model proses bisnis yang dituangkan dalam bentuk alur proses bisnis (Gambar 2) dalam bentuk Usecase Diagram dan Activity Diagram yang secara detail dijelaskan pada (Tabel 4)

Tahapan implementasi merupakan bagian yang berhubungan dengan perancangan sistem, tahapan perancangan sesuai dengan desain pemodelan UML yang telah didesain yang bertujuan untuk mempermudah perancangan sistem, Peneliti menggunakan metode extreme programming dalam melakukan pengembangan sistem alasannya adalah extreme programming merupakan salah satu metodologi yang paling sering digunakan dalam agile development. Pada tahap implentasi aktivitas coding (pengkodean) yang dilakukan adalah membuat code dari satu desain yang telah ditentukan, kemudian dilanjutkan dengan refactoring yang bertujuan untuk restrukturisasi kode program computer yang ada tanpa mengubah perilaku eksternalnya, pada tahapan ini pengembang sistem melakukan kerja sama untuk membuat kode program dari satu bagian ke bagian lain, perangkat yang dibutuhkan dalam melakukan pengembangan sistem adalah Android Studio, Mysql, Mockupplus. Implementasi coding dilakukan dengan mengaplikasikan halaman web dalam bentuk HTML berdasarkan hasil perancangan isi pada aktivitas nontechnicalmember sedangkan implementasi isi dan 
fungsi logika dibuat dalam bentuk PHP, dengan aplikasi Android Studio dan MySQL. selain itu juga dilakukan evaluasi agar sistem yang dihasilkan sesuai dengan yang telah direncanakan.

Tahapan pengujian merupakan bagian kegiatan pengujian dengan menggunakan menggunakan kerangka kerja yang memungkinkan mereka untuk diotomatisasi sehingga dapat dijialankan dengan mudah dan dapat dijalankan berulang kali. Pengujian dilakukan dengan ISO 9126 dengan menggunakan beberap aspek seperti: fungsionalitas, Realiability, Usability, Efficiency, Maintainability dan Portability.

\section{HASIL DAN PEMBAHASAN}

Sesuai dengan tahapan desain yang telah dilakukan, maka pada penelitian ini menghasilkan sebuah desain sistem yang sebelumnya telah dilakukan analisis kebutuhan sistem guna pengembangan aplikasi media pembelajaran conversation pada homey english berbasis mobile. Desain yang dihasilkan berupa model proses bisnis, usecase diagram, activity diagram, class diagram dan desain interface yang dibutuhkan.

Model proses bisnis adalah suatu pendekatan grafis yang menyajikan aktivitas bisnis, peristiwa, kontrol aliran (flow control), pemangku kepentingan (stakeholder), dan hubungan (relationship). proses bisnis adalah sebagai serangkaian tugas terkait secara logis yang dilakukan untuk mencapai hasil bisnis yang ditentukan berdasarkan tiga dimensi, (1) entitas: proses yang berlangsung antara entitas organisasi, antar entitas, antar fungsi atau antar pribadi, (2) objek : proses yang dihasikan melalui manipulasi objek dapat berupa fisik atau informasi, (3) aktivitas : proses yang melibatkan dua jenis kegiatan, manajerial dan operasional [22]. Proses bisnis adalah serangkaian kegiatan terstruktur yang dirancang untuk menghasilkan hasil terukur yang ditentukan untuk pelanggan atau pasar tertentu. Pemahaman umum di balik Business Process Management (BPM) adalah bahwa cara unik masing-masing perusahaan dalam menjalankan bisnis di tangkap dalam proses bisnisnya. Dalam beberapa tahun terakhir, BPM telah menjadi alat umum dalam proyek TI yang lebih besar dan mesin alur kerja yang dapat menjalankan proses bisnis menjadi cukup populer. Proses bisnis saat ini dipandang sebagai aset perusahaan yang paling berharga, M-learning homey english melibatkan tiga (3) entitas utama yaitu : pelajar, guru, dan admin, seperti pada (Gambar 2) [23].

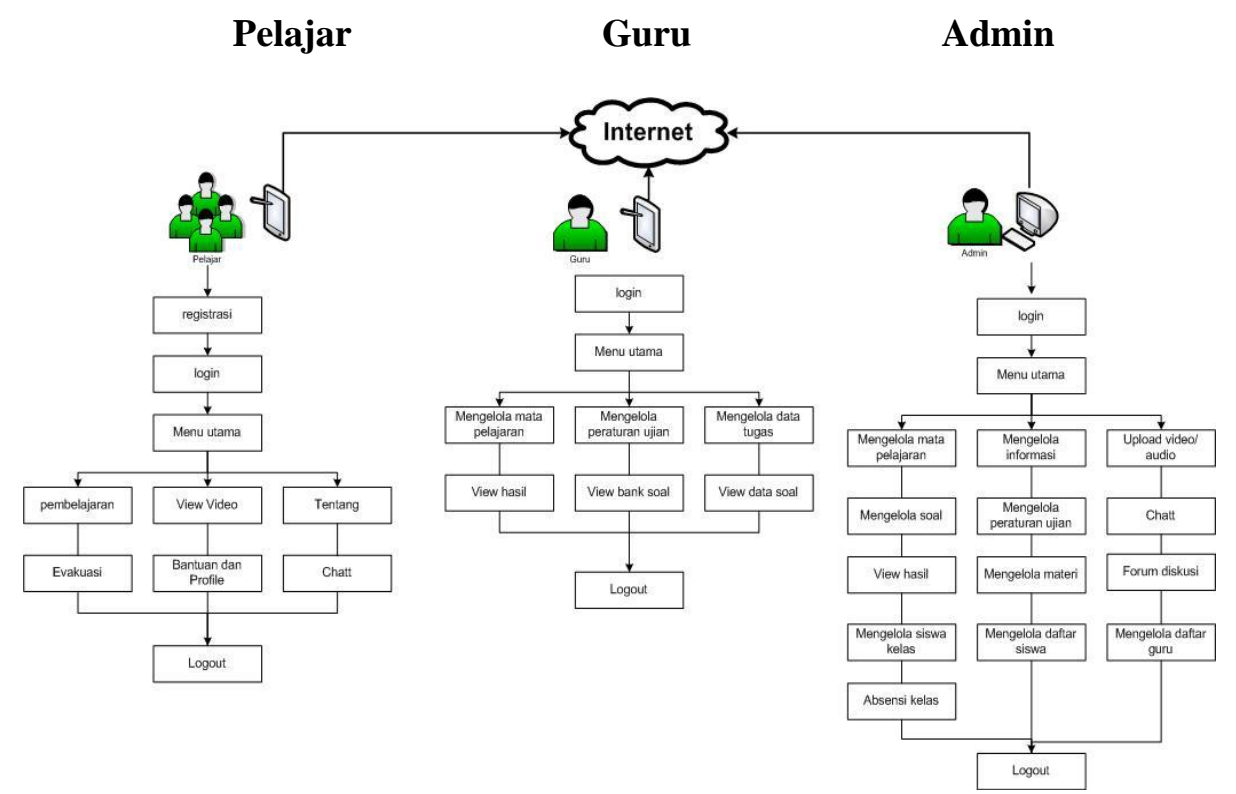

Gambar 2. Proses Bisnis M-Learning Homey English , [23]

Diagram use case adalah salah satu diagram yang membentuk UML (Unified Modeling Language), berfungsi untuk mengidentifikasi kasus penggunaan, serangkaian tindakan yang satu sistem dapat berjalan dalam skenario, dan aktor, yang mewakili faktor eksternal (pengguna atau sistem eksternal) yang berinteraksi dengan sistem [24], Unified Modelling Language (UML) adalah bahasa standar untuk pemodelan perangkat lunak dan model proses bisnis dan muncul sebagai standar 
umum untuk pemodelan paradigma berorientasi objek [25]. Use case mendeskripsikan sebuah interaksi antara satu atau lebih aktor dengan sistem informasi yang akan dibangun. Selain itu use case juga dapat digunakan untuk mengetahui fungsi apa saja yang ada didalam sebuah sistem dan siapa saja yang berhak atas perintah-perintah yang ada pada sistem tersebut.

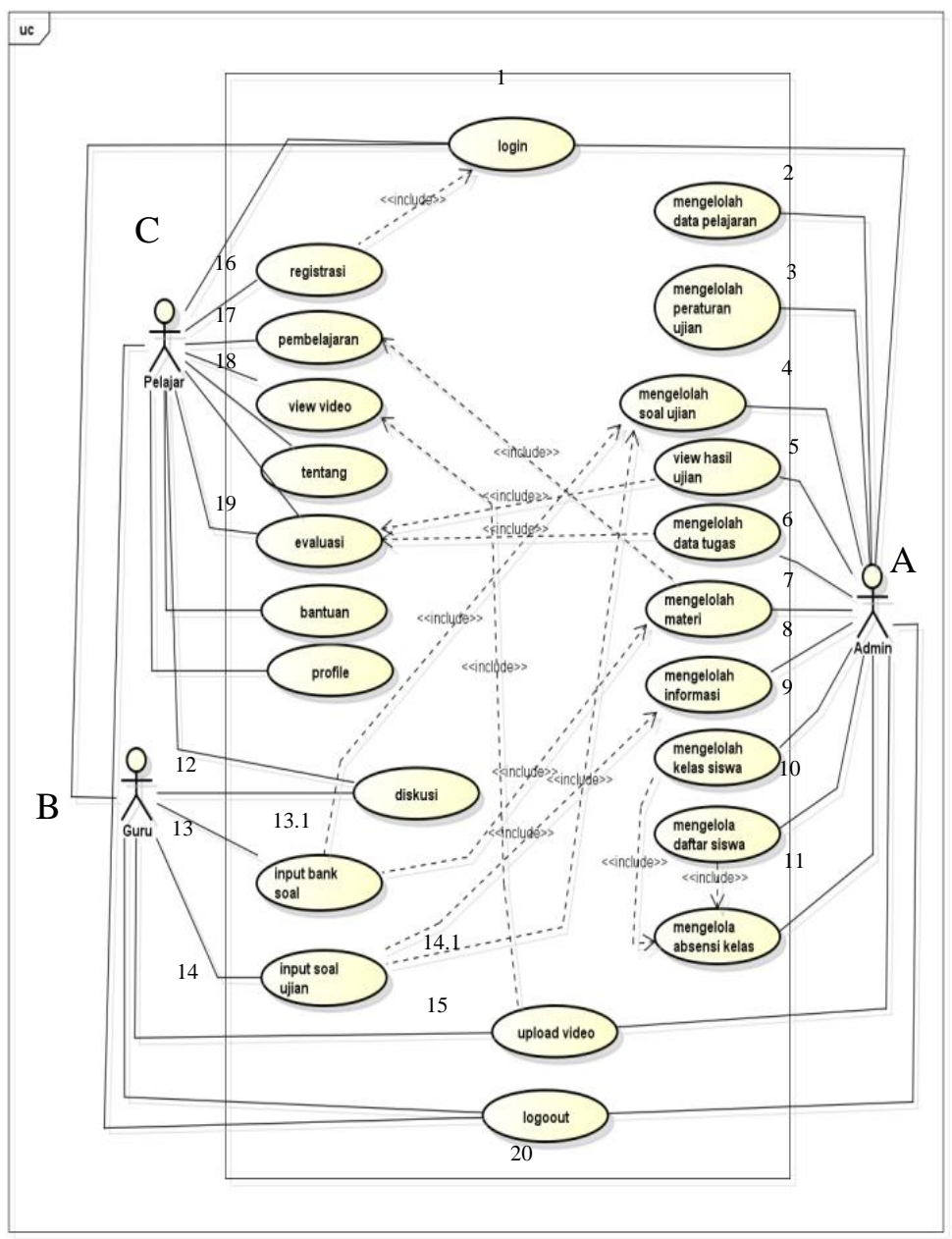

A : Admin

1. Login

2. Data processing studies

3. Test Settings

4. Processing exam questions

5. Showing Exam results

6. Processing task data

7. Processing Material

8. Processing information

9. Processing Classes (Students)

10. Processing Student Lists

11. Processing Class Attendance

20. Logout

\section{B : Guru}

1. Login

12. Manage discussion forums

13. Input Bank Questions

13.1. Processing exam questions

14. Input Test Questions

14.1 Processing exam question

15. Upload Video

20. Logout

C: Pelajar

1. Login

16. Subject Registration

17. Learning

18. Access Video

19. Evaluation

20. Logout

Gambar 3. Use Case Diagram Homey English

Diagram aktivitas UML (Unified Modeling Language) adalah diagram perilaku yang menggambarkan perilaku internal operasi yang berbeda dari suatu program dengan bantuan node dan edge [25]. Diagram aktivitas UML telah digunakan di berbagai domain untuk representasi alur kerja [26]. Activity diagram atau diagram berikut menggambarkan workflow (aliran kerja) aktivitas dari sebuah sistem yang terdiri dari 3 aktifitas berdasarkan pembagian aktor, yaitu : admin, guru dan pelajar. pada aktor admin, guru dan pelajar terdapat beberapa activity diagram seperti pada (Tabel 4), salah satu contoh alur activity diagram dapat dilihat pada gambar activity diagram input tugas (Gambar 4) dan activity diagram materi pembelajaran ( Gambar 5).

Pada diagram Use Case digunakan untuk menggambarkan fungsionalitas yang diharapkan dari suatu sistem. Use Case dapat menghadirkan interaksi antara aktor dengan sistem (Gambar 3). Proses ini dilakukan oleh pengguna (user) sehingga pengguna dapat memilih menu yang diperlukan dan rincian fungsi dan hak akses pada ketiga entitas dapat dilihat pada Tabel (Tabel 3). 
Tabel 3. Access Right Use Case Diagram Homey English

\begin{tabular}{|c|c|c|}
\hline Actor & Descriptions & Access Right \\
\hline Admin & $\begin{array}{l}\text { Aktor yang memiliki hak akses untuk } \\
\text { melakukan pengolahan data mata } \\
\text { pelajaran, mengelola data peraturan ujian, } \\
\text { soal ujian, hasil ujian, tugas, forum diskusi, } \\
\text { materi, video, informasi, siswa kelas, daftar } \\
\text { guru, daftar siswa, dan absensi kelas, chatt }\end{array}$ & $\begin{array}{l}\text { [Login], [Data processing studies], } \\
\text { [Test Settings], [Processing exam } \\
\text { questions], [Showing Exam results], } \\
\text { [Processing Material], [Processing } \\
\text { Classes (Students)], [Processing Student } \\
\text { Lists],[Processing Class Attendance], } \\
\text { [Upload Video], [Processing } \\
\text { information],[Logout] }\end{array}$ \\
\hline Student & $\begin{array}{l}\text { aktor yang memiliki hak akses } \\
\text { untuk melakukan pengolahan mata } \\
\text { pelajaran, peraturan ujian, view hasil, } \\
\text { mengelola data tugas, view bank soal, } \\
\text { view soal ujian, dan melakukan diskusi }\end{array}$ & $\begin{array}{l}\text { [Login], [Subject Registration], } \\
\text { [[Learning],[access lessons],[access exam } \\
\text { results]], [Access Video], [[Evaluation], } \\
\text { [access assignments]], [Following the } \\
\text { discussion], [Logout] }\end{array}$ \\
\hline Teacher & $\begin{array}{l}\text { Pihak harus melakukan registrasi dan } \\
\text { yang memiliki hak akses untuk } \\
\text { mengerjakan pembelajaran, video, } \\
\text { tentang, evaluasi, bantuan, profile, } \\
\text { melakukan diskusi }\end{array}$ & $\begin{array}{l}\text { [Login], [Manage discussion forums], } \\
\text { [Input Bank Questions, [Processing exam } \\
\text { questions]], [Input Test } \\
\text { Questions],[Processing task data] } \\
\text { [Upload Video], [Logout] }\end{array}$ \\
\hline
\end{tabular}

Tabel 4. Daftar Activity Diagram Homey English

\begin{tabular}{lccc}
\hline \multicolumn{1}{c}{ Activity Diagram } & Admin & guru & pelajar \\
\hline Login & $\sqrt{ }$ & $\sqrt{ }$ & $\sqrt{ }$ \\
Data processing studies & $\sqrt{ }$ & & \\
Test Settings & $\sqrt{ }$ & & $\sqrt{ }$ \\
Showing Exam results & $\sqrt{ }$ & $\sqrt{ }$ Implement & \\
Processing task data & $\sqrt{ }$ & & \\
Processing Material & $\sqrt{ }$ & & \\
Processing Classes (Students) & $\sqrt{ }$ & & \\
Processing Student Lists & $\sqrt{ }$ & $\sqrt{ }$ & \\
Processing Class Attendance & & $\sqrt{ }$ & \\
Manage discussion forums & & $\sqrt{ }$ & \\
Input Bank Questions & & $\sqrt{ }$ & $\sqrt{ }$ \\
Processing exam questions & & $\sqrt{ }$ & $\sqrt{ }$ \\
Input Test Questions & & & $\sqrt{ }$ \\
Upload Video & & & \\
Subject Registration & & & \\
Learning & & $\sqrt{ }$ \\
Access Video & $\sqrt{ }$ & \\
Evaluation & & & \\
Logout & & & \\
\hline
\end{tabular}

Pada tahap desain, alat UML yang paling banyak diterapkan adalah diagram kelas (CD). Keuntungan utama UML adalah ekspresif yang tinggi dan sifat deklaratif, kekayaan struktur, yang secara negatif mempengaruhi kemampuan verifikasi otomatis [27].

Rancangan desain form menjelaskan atau mendeskripsikan rancangan antar muka dari program yang akan dibuat. Berikut adalah rancangan antar muka m-learning homey english: pada form menu utama siswa (Gambar 6), siswa harus memasukan username dan password untuk dapat mengakses aplikasi. Rancangan antarmuka menu utama (Gambar 6), Menu soal (Gambar 7) dan menu tugas (Gambar 8), dapat dilihat pada gambar berikut: 


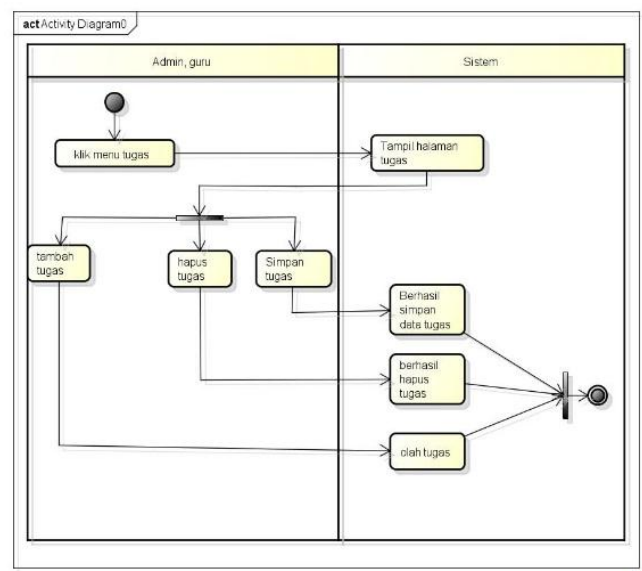

Gambar 4. Activity Diagram Input Tugas

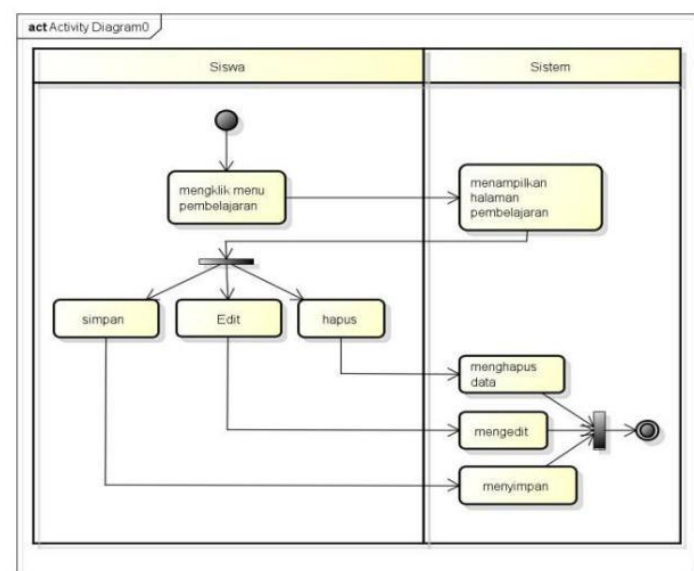

Gambar 5. Activity Diagram Materi Pelajaran

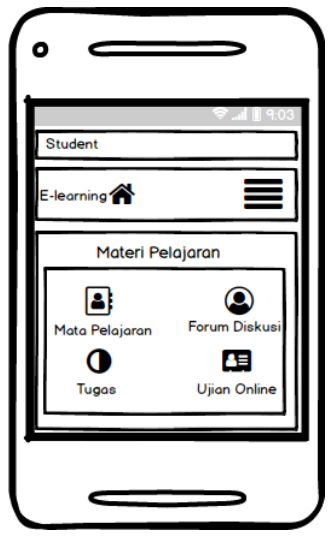

Gambar 6. Menu Utama

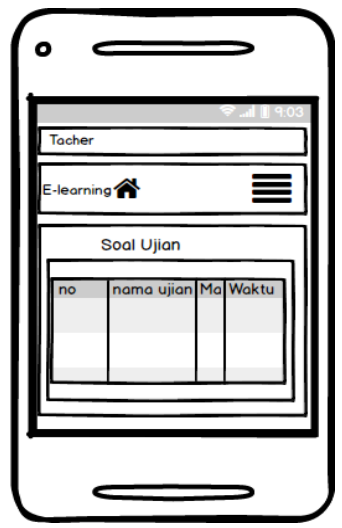

Gambar 7. Menu Soal

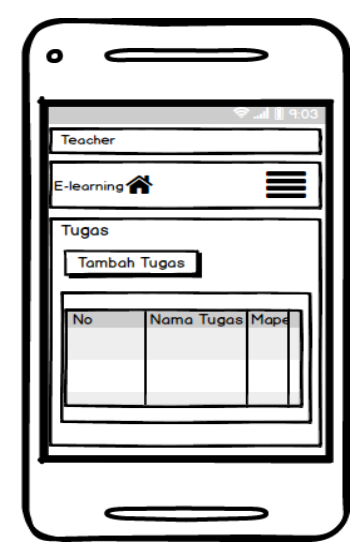

Gambar 8. Menu Tugas

Rancangan desain form web admin mendeskripsikan rancangan antar muka dari program yang akan dibuat. Berikut adalah rancangan interface m-learning homey english: pada form mata pelajaran (Gambar 9), form desain menu soal ujian (Gambar 10), implentasinya dapat diakses melalui halaman web browser, fungsi dari halaman admin mata pelajaran bertujuan untuk mengisi data-data yang terkait dengan proses pembelajaran seperti subjek pelajaran, bank soal, membuat ujian, pertanyaan ujian, aturan pelaksanaan ujian, forum diskusi, pengaturan artikel, video, menambah informasi perkuliahan, daftar guru dan daftar pelajar mengisi daftar pelaksanaan ujian seperti nama ujian, waktu ujian dan aturan penilaian yang akan dilaksanakan oleh peserta pada saat melakukan ujian. 


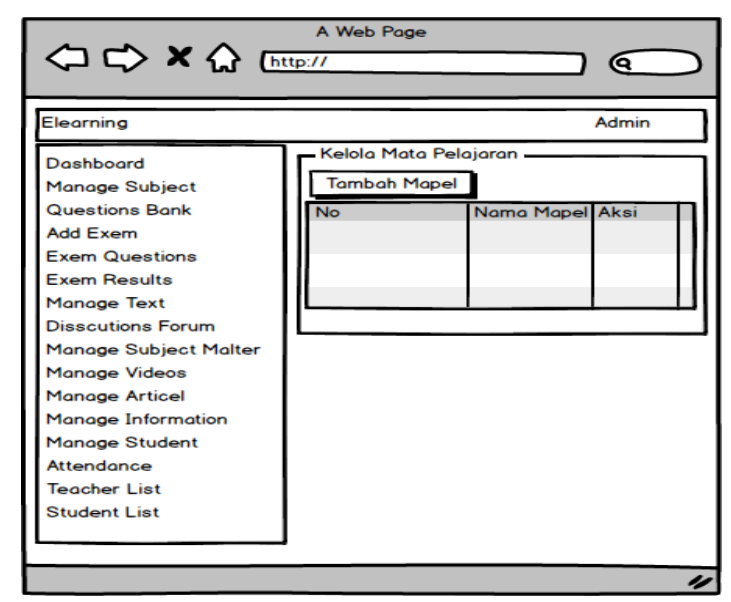

Gambar 9. Desain Menu Mata Pelajaran

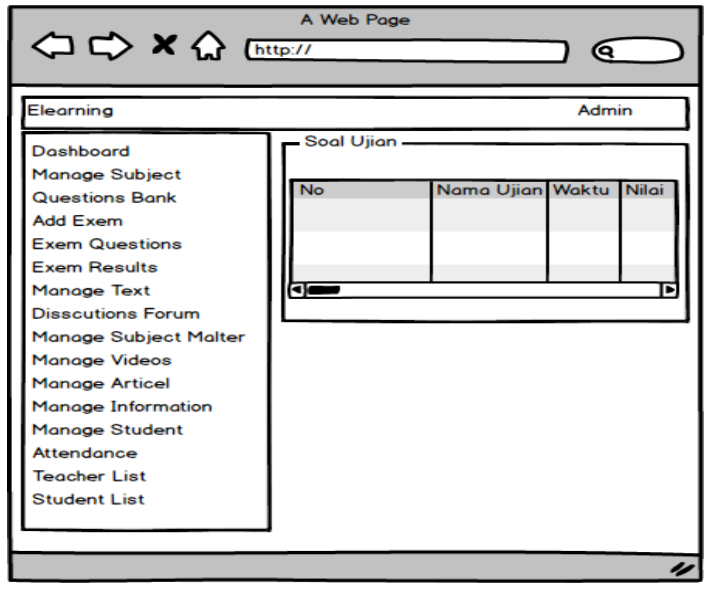

Gambar 10. Desaian Menu Soal Ujian

Proses pembelajaran pada aplikasi m-learing homey english dapat di akses melalui menu utama (Gambar 11), proses pembelajaran terdiri dari beberapa tahapan yaitu, (1) siswa mengakses materi pembelajaran pada menu materi yang telah tersedia (Gambar 12) dan dapat mengakses materi video (Gambar 13) yang sesuai dengan tahapan pembelajaran. (2) tahap selanjutnya siswa mengakses forum diskusi (Gambar 15), forum diskusi merupakan proses interaksi antara guru dan siswa, (3) siswa mengerjakan tugas-tugas yang diberikan oleh guru, (4) siswa mengerjakan ujian secara daring, selain itu siswa juga dapat melihat soal-soal yang telah dikerjakan dalam bentuk pembahasan seperti pada (Gambar 16), guru dapat melihat secara langsung log activity dan informasi tentang mata pelajaran yang dikelola dalam bentuk dashbard (Gambar 14), informasi dashboard terdiri dari (student passed, student not passed, total students dan total question).

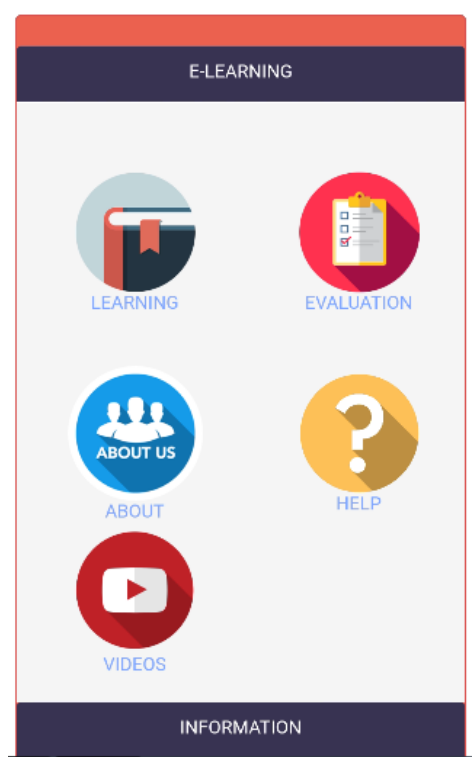

Gambar 11. Menu Utama

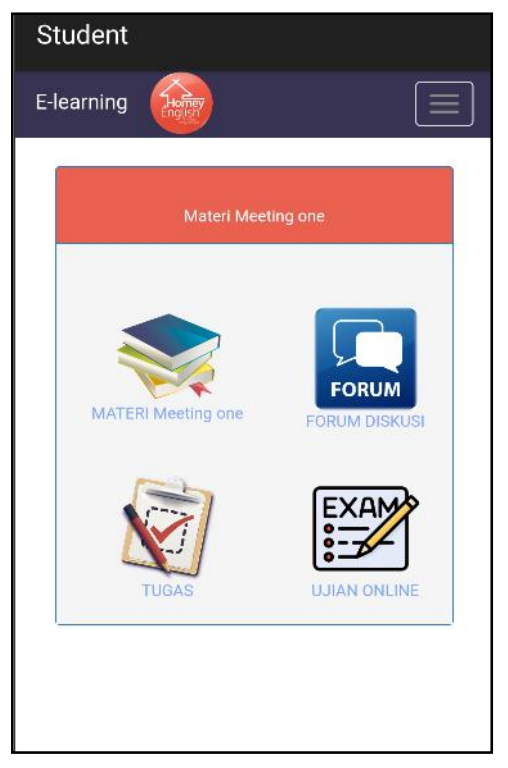

Gambar 12. Menu Student

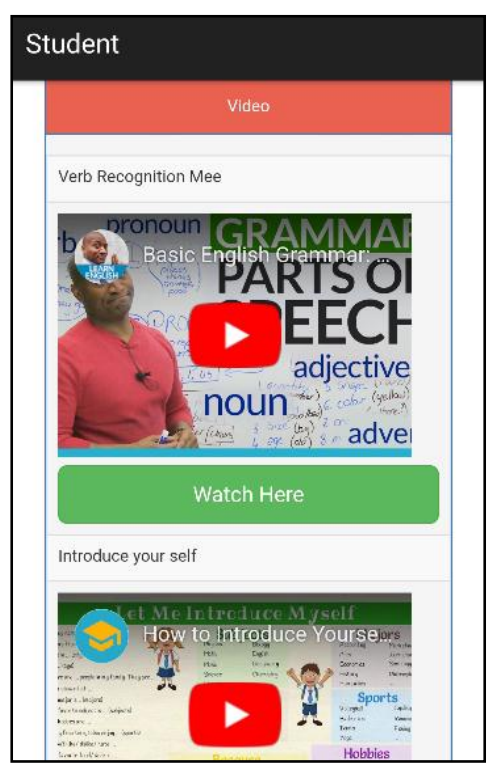

Gambar 13. Menu Video

Melalui aplikasi m-learning homey english guru dapat mengakses menu khusus yang dikelola oleh guru, selain itu guru dapat memberikan penugasan melalui beberapa fungsi yang ada di aplikasi m-learning homey english dan menetapkan beberapa aturan-aturan yang akan diberlakukan pada siswa, misalnya peraturan ujian, penilaian dan status level pada setiap materi yang diujikan pada mata pelajaran english conversation. 


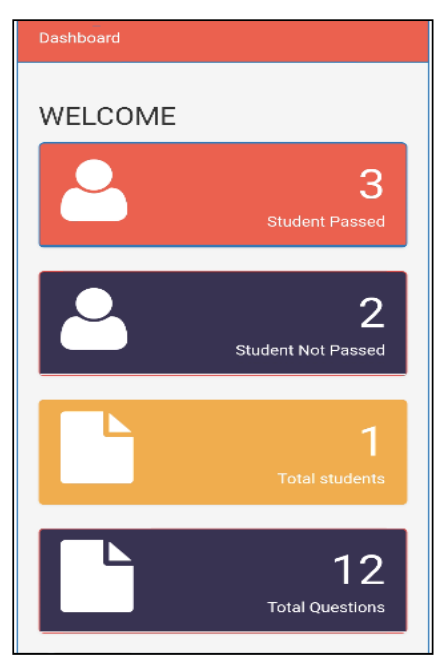

Gambar 14. Dashboard

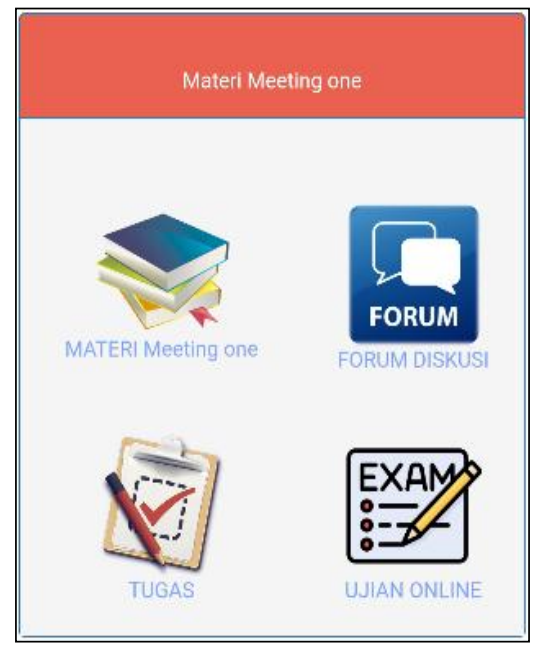

Gambar 15. Menu Meeting

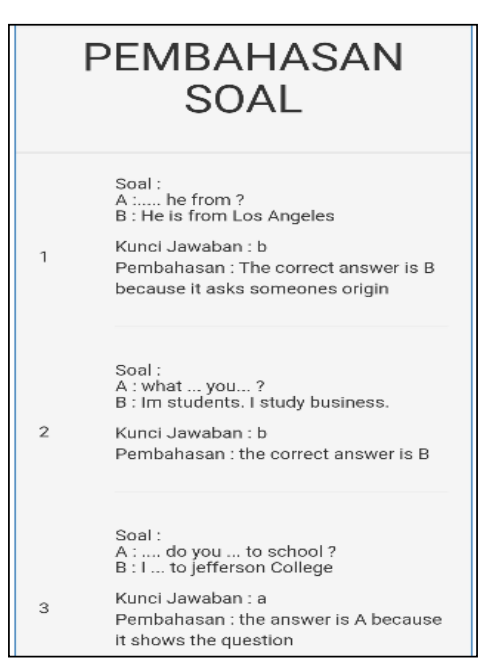

Gambar 16. Pembahasan

Soal

Pengaturan waktu ujian (Gambar 17), merupakan bagian dari pengelolaan ujian yang diatur oleh guru agar dapat merubah durasi waktu pelaksanaan ujian dan menambahkan aturan dan aksi yang dapat dilakukan oleh siswa. Pengaturan tugas (Gambar 18), adalah bagian pengelolaan tugas conversation seperti pengaturan nama tugas, level tugas conversation, pembagian tugas berdasarkan kelas dan pengaturan deskripsi tugas.

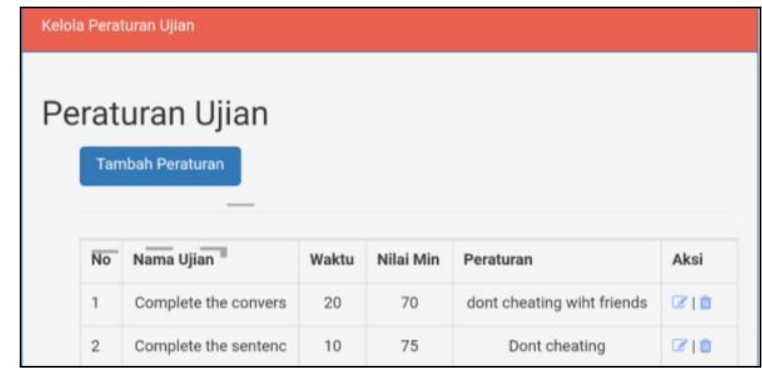

Gambar 17. Pengaturan Ujian

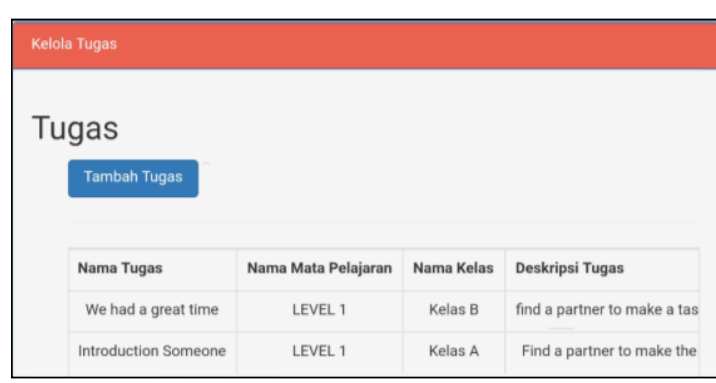

Gambar 18. Pengaturan Tugas

Evaluasi pembelajaran yang dilakukan pada pembelajaran english conversation adalah dengan memberikan soal-soal latihan pada siswa, oleh karena itu guru perlu mempersiapkan soal-soal apa saja yang harus diberikan kepada siswa pada bank soal yang telah disediakan pada aplikasi $\mathrm{m}$ learning homey english, selain itu guru juga dapat mengelola soal ujian dengan membuat pertanyaan dan mengatur durasi waktu batas mengerjakan dan mengatur minimum grade yang dibutuhkan untuk lulus berdasarkan pengaturan ujian yang telah ditetapkan oleh guru (Gambar 19), setelah guru mempersiapkan pertanyaan-pertanyaan yang akan diujikan kepada siswa selanjutnya guru dapat mengolah pertanyaan-pertanyaan menjadi sebuah bank soal yang telah disediakan pada bagian bank soal (Gambar 20). kemudian bank soal dapat di sajikan menjadi aktifitas pelaksanaan ujian yang dilaksanakan oleh siswa sesuai dengan pengaturan ujian yang telah ditetapkan oleh guru. 


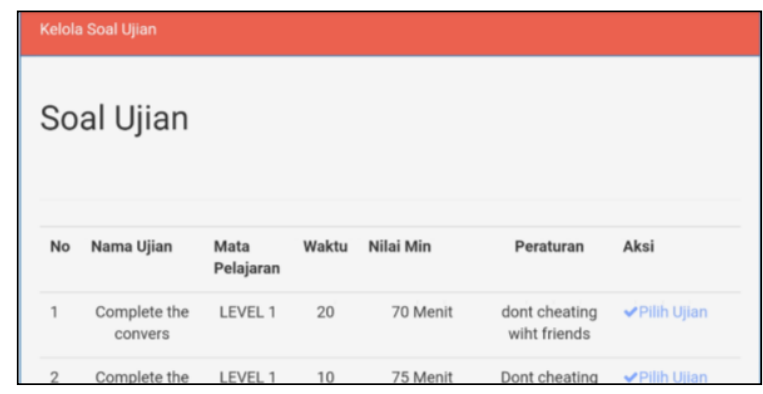

Gambar 19. Pengaturan Ujian

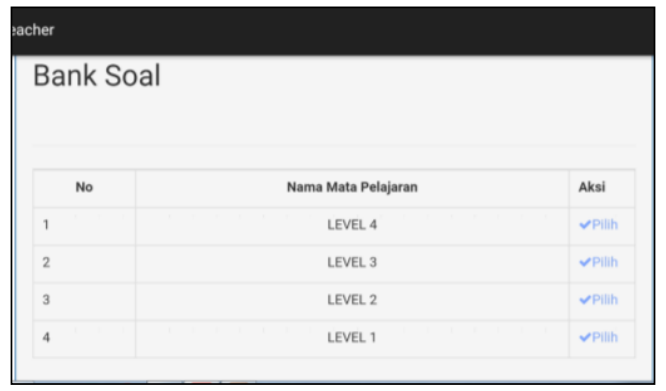

Gambar 20. Bank Soal

Hasil pelaksanaan ujian yang telah dilakukan oleh siswa dapat dilihat oleh guru dengan mengakses bagian hasil tes ujian siswa (Gambar 22).

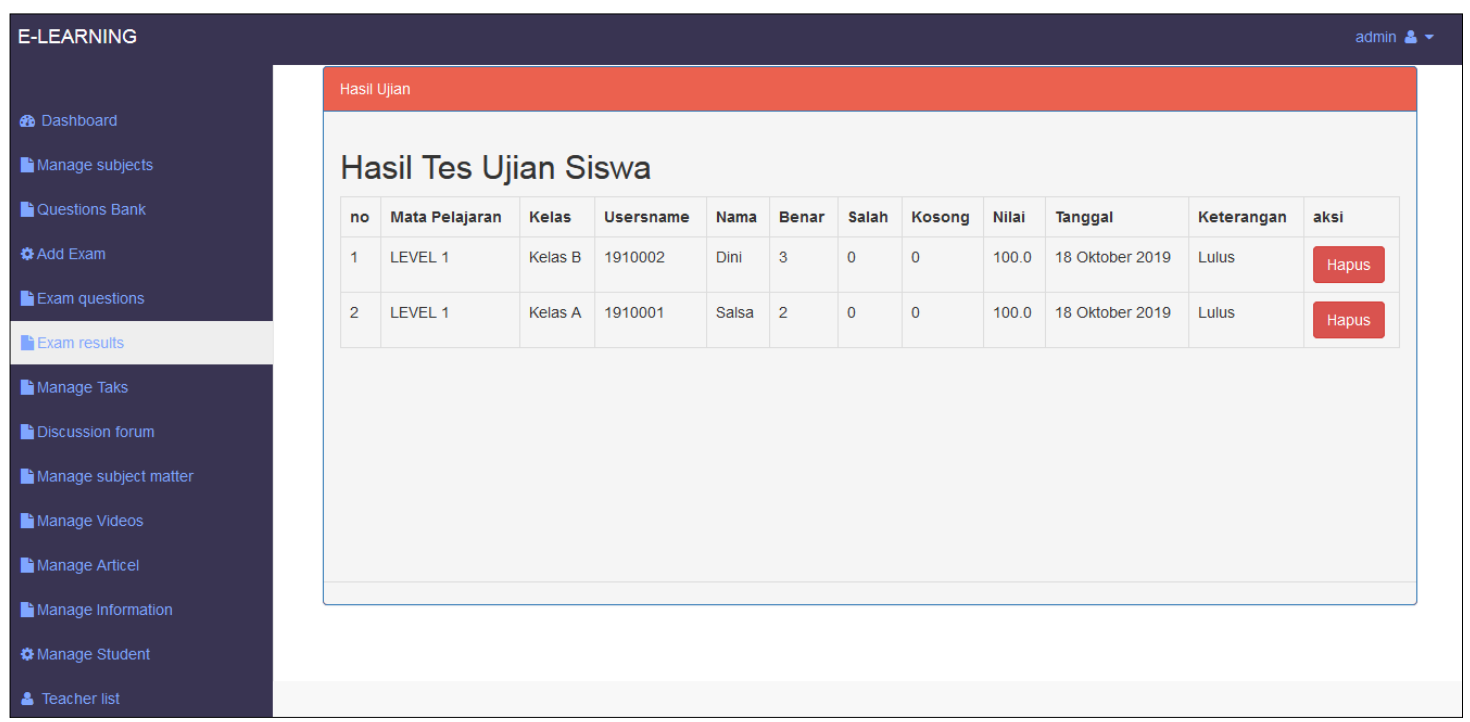

Gambar 21. Hasil Tes Ujian Siswa

Pada bagian hasil tes ujian siswa (Gambar 21), guru dapat melihat secara detail tentang pelaksanaan ujian english conversation yang telah diberikan kepada siswa seperti, jumlah pertanyaan benar dan jumlah pertanyaan salah yang dikerjakan oleh siswa, informasi siswa, nilai, tanggal dan waktu pengerjaan dan keterangan hasil ujian.

Untuk memastikan kualitas dalam sistem perangkat lunak tidak hanya dibutuhkan pemantauan dan manajemen, tetapi juga kepatuhan terhadap standar yang ketat. Melalui pengukuran dan metrik, industri perangkat lunak akan memeriksa produk dan layanan yang memenuhi persyaratan [25]. Pengujian dilakukan dengan menggunakan standar ISO 9126 yang menggunakan dua variabel. Variabel yang digunakan adalah functionality dan usability. Pengujian dilakukan dengan memberikan kuesioner kepada 25 (dua puluh lima) responden. Dari dua puluh lima responden, semua memberikan jawaban kuesioner dengan valid. Tanggapan responden terhadap kualitas aplikasi ini dapat diukur dengan menggunakan rumus sebagai berikut:

$$
\text { Result }=\frac{\text { Actual Score }}{\text { Ideal Score }} \times 100 \%
$$

Skor aktual adalah jawaban seluruh responden atas kuesioner yang telah diajukan. Skor ideal adalah skor atau bobot tertinggi atau semua responden diasumsikan memilih jawaban dengan skor tertinggi. Tingkat kualitas perangkat lunak pada setiap aspek berdasarkan hasil jawaban kuesioner yang telah dijawab oleh para responden adalah :

functionality merupakan salah satu aspek pengujian standar ISO 9126 yang mengukur kemampuan perangkat lunak untuk menyediakan fungsi sesuai kebutuhan pengguna ketika digunakan 
dalam kondisi tertentu [28]. Jumlah kuesioner terdiri dari 15 pertanyaan positif yang didalamnya terdapat 5 aspek indikator yaitu suitability, interoperability, Gambar 18 Pengaturan Tugas

accurancy, security dan compliance. Berikut adalah hasil pengujian functionality (Tabel 5), yang telah dilakukan. Hasil penilaian kuesioner functionality admin pada aplikasi dengan butir pertanyaan sebanyak 15 buah. Berikut hasil pengujian kuesioner functionality admin dapat dilihat pada (Tabel 6) di bawah ini :

Tabel 5. Daftar Pertanyaan Pengujian Aspek functionality

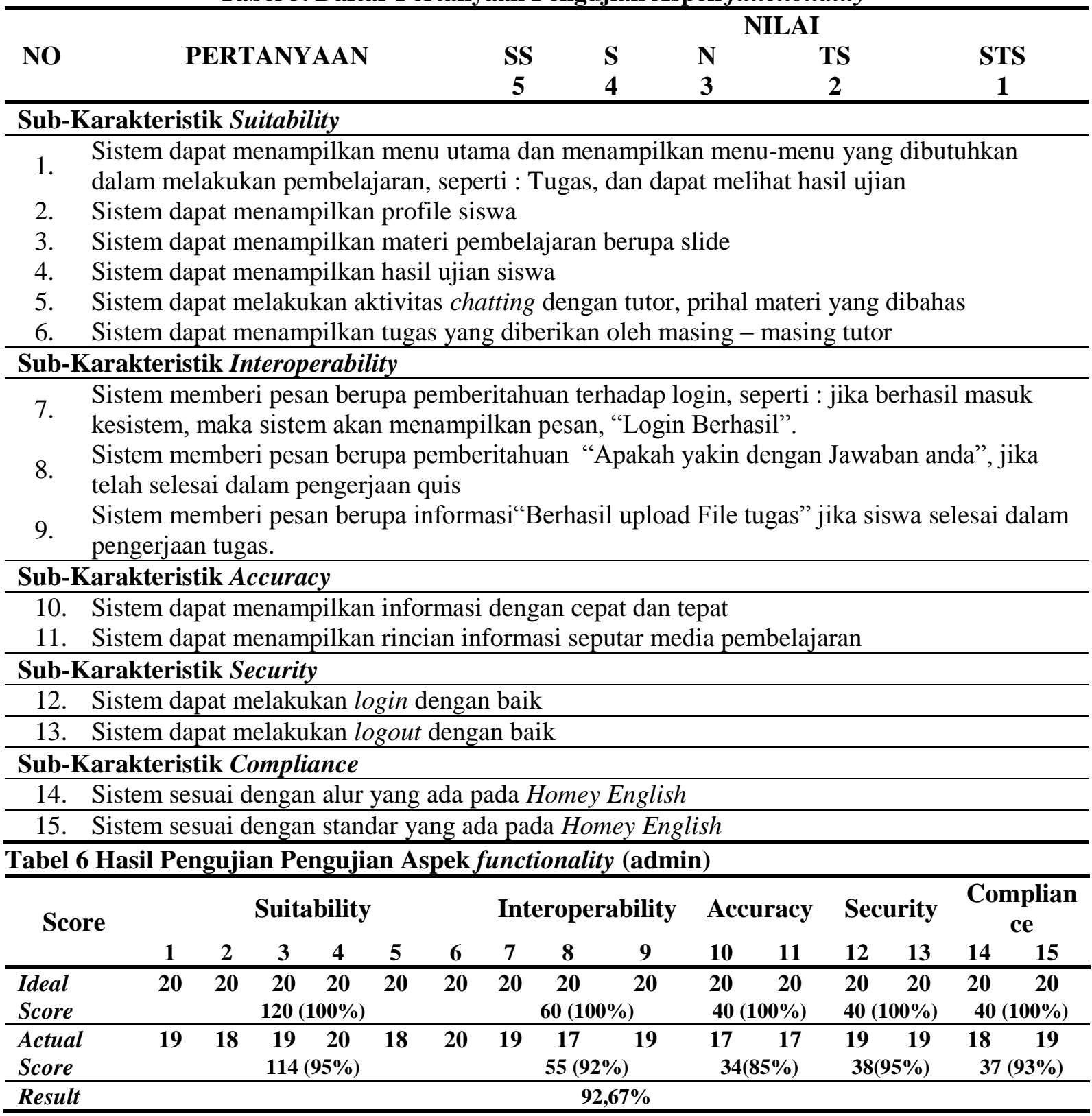



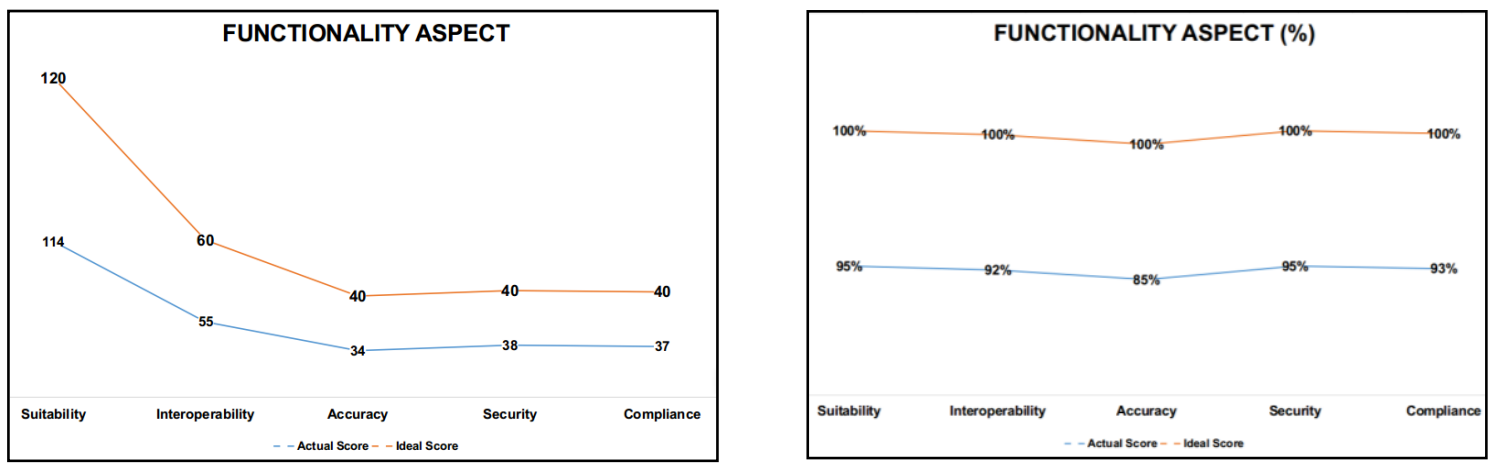

Gambar 22. Pengujian Aspek Fungsionalitas (Admin)

Berdasarkan hasil pengujian kualitas perangkat lunak yang dibangun dengan karakteristik functionality (Admin) dengan menggunakan 4 responden, pada aplikasi yang dibangun memiliki hasil persentase keberhasilan sebesar $92.67 \%$ yang terdiri dari : suitability 95\%, interoperability 92\%, accuracy $85 \%$, security 95\% dan compliance 93\%, dapat dilihat pada (Tabel 6) dan (Gambar 22), nilai yang diperoleh tersebut selanjutnya dikonversi berdasarkan skala konversi nilai produk. Dapat disimpulkan bahwa nilai persentase yang diperoleh menunjukkan kualitas perangkat lunak karakteristik functionality mempunyai skala "Sangat Baik", sehingga dapat disimpulkan bahwa aplikasi yang dibangun sudah memenuhi karakteristik functionality

Tabel 7. Hasil Pengujian Pengujian Aspek Functionality (Siswa)

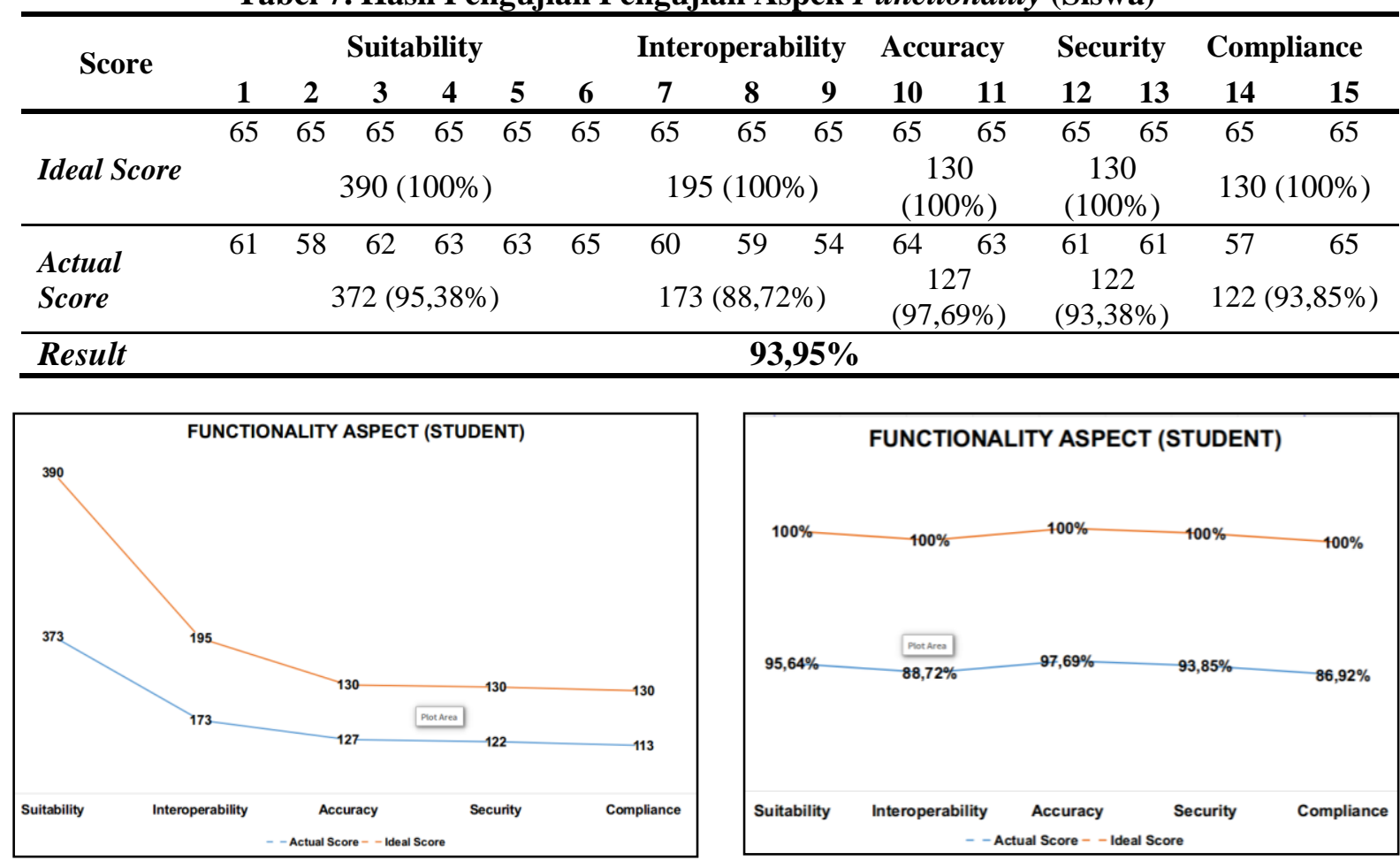

\section{Gambar 23. Pengujian Aspek Functionality (Siswa)}

Berdasarkan hasil pengujian kualitas perangkat lunak yang dibangun menggunakan karakteristik functionality (siswa) dengan 13 responenden pada aplikasi yang dibangun memiliki hasil persentase keberhasilan sebesar $93.95 \%$ yang terdiri dari : suitability $95,38 \%$, interoperability 88,72\%, accuracy 97,69\%, security 93,38\% dan compliance 93,85\%, dapat dilihat pada (Tabel 7) dan (Gambar 23), nilai yang diperoleh tersebut selanjutnya dikonversi berdasarkan skala konversi nilai produk. Dapat disimpulkan bahwa nilai persentase yang diperoleh menunjukkan kualitas perangkat lunak karakteristik functionality mempunyai skala "Sangat Baik" sehingga dapat dikatakan bahwa aplikasi yang dibangun sudah memenuhi karakteristik functionality 
Usability merupakan bagian dari standar ISO 9126 yang mengukur kemampuan perangkat lunak untuk menyediakan fungsi sesuai kebutuhan pengguna, ketika digunakan dalam kondisi tertentu [29]. pada pengujian usability (admin) terdiri dari 4 responden dengan jumlah kuesioner terdiri dari 5 pertanyaan positif yang didalamnya terdapat 4 aspek indikator yaitu understandibility, learnability, operability, dan attractiveness. Berikut adalah hasil pengujian usability (Tabel 8), yang telah dilakukan. Hasil penilaian kuesioner usability admin pada aplikasi dengan butir pertanyaan sebanyak 5 pertanyaan (Tabel 8). Berikut hasil penilaian kuesioner usability (admin) dapat dilihat pada (Tabel 9) dan (Gambar 24). pada pengujian usability (siswa) terdiri dari 12 responden dengan 5 pertanyaan positif yang didalamnya terdapat 4 aspek indikator serupa dengan pengujian usability (admin). Hasil penilaian kuesioner usability (siswa) dapat dilihat pada (Tabel 10) dan (Gambar 25).

Tabel 8. Daftar Pertanyaan Pengujian Aspek Usability

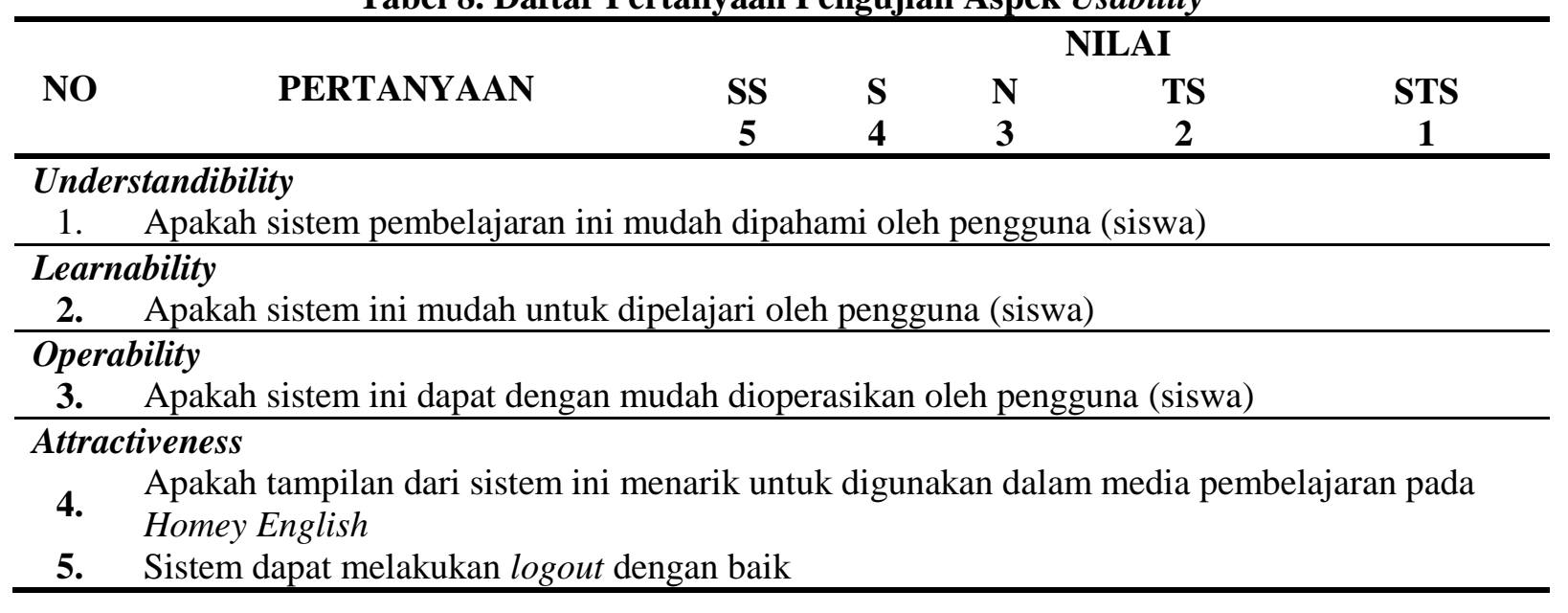

Tabel 9. Hasil Pengujian Pengujian Aspek Usability (Admin)

\begin{tabular}{|c|c|c|c|c|}
\hline & $\begin{array}{c}\text { Understandibilit } \\
y \\
1 \\
\end{array}$ & $\begin{array}{c}\text { Learnabilit } \\
y \\
2 \\
\end{array}$ & $\begin{array}{c}\text { Operability } \\
\mathbf{3} \\
\end{array}$ & $\begin{array}{c}\text { Attractiveness } \\
4 \\
\end{array}$ \\
\hline Ideal Score & $\begin{array}{c}20 \\
20(100 \%) \\
\end{array}$ & $\begin{array}{c}20 \\
20(100 \%) \\
\end{array}$ & $\begin{array}{c}20 \\
20(100 \%) \\
\end{array}$ & $\begin{array}{c}20 \\
20(100 \%) \\
\end{array}$ \\
\hline Actual Score & $\begin{array}{c}19 \\
19(95 \%) \\
\end{array}$ & $\begin{array}{c}20 \\
20(100 \%)\end{array}$ & $\begin{array}{c}20 \\
20(100 \%)\end{array}$ & $\begin{array}{c}18 \\
18(90 \%) \\
\end{array}$ \\
\hline Result & & & $96,25 \%$ & \\
\hline
\end{tabular}

Tabel 10. Hasil Pengujian Pengujian Aspek Usability (Siswa)

\begin{tabular}{|c|c|c|c|c|}
\hline $\begin{array}{c}\text { Responde } \\
\text { nt }\end{array}$ & $\begin{array}{c}\text { Understandibilit } \\
\mathbf{y} \\
1 \\
\end{array}$ & $\begin{array}{c}\text { Learnabilit } \\
\mathbf{y} \\
\mathbf{2} \\
\end{array}$ & $\begin{array}{c}\text { Operability } \\
\mathbf{3} \\
\end{array}$ & $\begin{array}{c}\text { Attractiveness } \\
5\end{array}$ \\
\hline Ideal Score & $\begin{array}{c}65 \\
65(100 \%) \\
\end{array}$ & $\begin{array}{c}65 \\
65(100 \%) \\
\end{array}$ & $\begin{array}{c}57 \\
65(100 \%) \\
\end{array}$ & $\begin{array}{c}56 \\
65(100 \%) \\
\end{array}$ \\
\hline $\begin{array}{l}\text { Actual } \\
\text { Score }\end{array}$ & $\begin{array}{c}61 \\
93,85\end{array}$ & $\begin{array}{c}19 \\
93,85\end{array}$ & $\begin{array}{c}18 \\
87,69\end{array}$ & $\begin{array}{c}19 \\
86,15\end{array}$ \\
\hline Result & & & $93,85 \%$ & \\
\hline
\end{tabular}




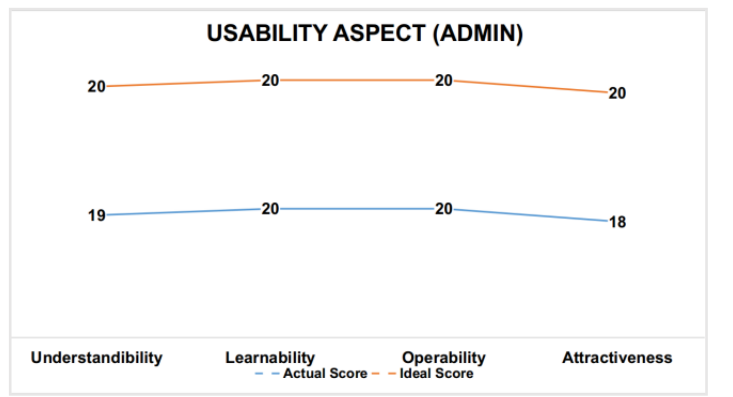

Gambar 24. Pengujian Aspek Usability (Admin)

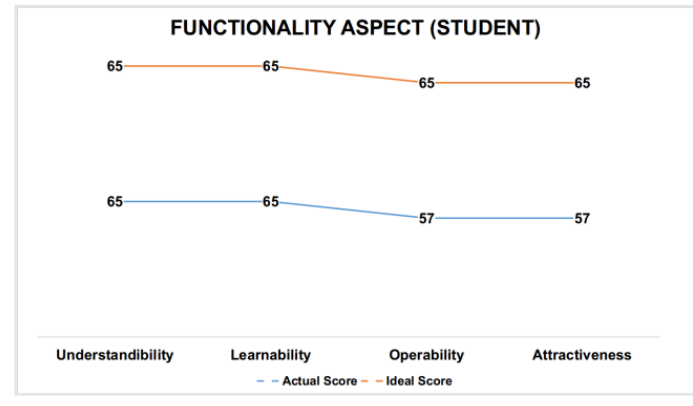

Gambar 25. Pengujian Aspek Usability (Siswa)

\section{KESIMPULAN}

Berdasarkan pembahasan yang telah dilakukan maka dapat diambil kesimpulan yaitu : Perancangan dan pembangunan aplikasi untuk pembelajaran english conversation dapat diimplementasikan dengan baik sesuai dengan pelaksanaan pembelajaran pada homey english dengan menerapkan mekanisme proses pembelajaran seperti persiapan bahan ajar, pelaksanaan proses pembelajaran dan pelaksanaan evaluasi pembelajaran dengan memberikan soal-soal ujian kepada siswa dengan menggunakan fasilitas yang telah disediakan pada aplikasi, Perancangan dan pembangunan aplikasi media pembelajaran yang telah diuji menggunakan ISO 9126 memiliki persentase keberhasilan pada aspek functionality (admin) 92,7\%, functionality (siswa) 93,95\% dan pada aspek usability (admin) 96,25\%, usability (siswa) 93,85\%. Media pembelajaran yang dibangun dapat diakses dengan mendownload aplikasi yang telah disediakan sehingga bagi siswa, guru, dan admin dapat mengurangi kualitas belajar seperti pada tatap muka.

\section{REFERENSI}

[1] G. Krull and J. M. Duart, "Research trends in mobile learning in higher education: A systematic review of articles (2011 - 2015)," Int. Rev. Res. Open Distance Learn., vol. 18, no. 7, pp. 1-23, 2017, doi: 10.19173/irrodl.v18i7.2893.

[2] J. Surjanti et al., "The role of M-learning on effective learning media in higher education," Int. J. Civ. Eng. Technol., vol. 9, no. 4, pp. 77-85, 2018.

[3] A. Abu-Al-Aish and S. Love, "Factors influencing students' acceptance of m-learning: An investigation in higher education," Int. Rev. Res. Open Distance Learn., vol. 14, no. 5, pp. 82107, 2013, doi: 10.19173/irrodl.v14i5.1631.

[4] Y. S. Wang, M. C. Wu, and H. Y. Wang, "Investigating the determinants and age and gender differences in the acceptance of mobile learning," Br. J. Educ. Technol., vol. 40, no. 1, pp. 92118, 2009, doi: 10.1111/j.1467-8535.2007.00809.x.

[5] Y. T. Sung, H. Y. Lee, J. M. Yang, and K. E. Chang, "The quality of experimental designs in mobile learning research: A systemic review and self-improvement tool," Educ. Res. Rev., vol. 28, no. April, p. 100279, 2019, doi: 10.1016/j.edurev.2019.05.001.

[6] N. B. Manjale and C. Abel, "Significance and adequacy of instructional media as perceived by primary school pupils and teachers in Kinondoni District, Tanzania," Int. J. Educ. Policy Res. Rev., vol. 4, no. 6, pp. 151-157, 2017, doi: 10.15739/IJEPRR.17.016.

[7] A. A. Sakat, M. Z. Mohd Zin, R. Muhamad, A. Ahmad, N. A. Ahmad, and M. A. Kasmo, "Educational technology media method in teaching and learning progress," Am. J. Appl. Sci., vol. 9, no. 6, pp. 874-878, 2012, doi: 10.3844/ajassp.2012.874.878.

[8] Z. L. Berge, L. Y. Muilenburg, N. York, and T. Cochrane, "HANDBOOK OF Edited by Foundations and Future," no. October, pp. 108-123, 2016.

[9] N. Bukharaev and A. Wisam Altaher, "Mobile Learning Education has Become More Accessible," Am. J. Comput. Sci. Inf. Technol., vol. 05, no. 02, pp. 3-7, 2017, doi: 10.21767/2349-3917.100005.

[10] R. Alhajri, "Prospects and Challenges of Mobile Learning Implementation: A Case Study," J. Inf. Technol. Softw. Eng., vol. 06, no. 05, 2016, doi: 10.4172/2165-7866.1000189. 
[11] T. H. Fitts, "Teacher Implementation Of Mobile Learning Initiative At A Sixth Grade School: A Phenomenological Study,” Liberty University, Lynchburg, VA, 2015.

[12] V. I. Toktarova, A. D. Blagova, A. V. Filatova, and N. V. Kuzmin, "Design and implementation of mobile learning tools and resources in the modern educational environment of university," Rev. Eur. Stud., vol. 7, no. 8, pp. 318-324, 2015, doi: 10.5539/res.v7n8p318.

[13] O. O.D, "Relevance of Educational Media and Multimedia Technology for Effective Service Delivery in Teaching and Learning Processes," IOSR J. Res. Method Educ., vol. 4, no. 2, pp. 48-51, 2014, doi: 10.9790/7388-04214851.

[14] M. Aksa, "Classification and Characteristics of Historical Learning Media," vol. 158, no. Ictte, pp. 37-43, 2017, doi: 10.2991/ictte-17.2017.1.

[15] L. Nurpratiwiningsih and D. T. Setiyoko, "Development of Education Games Map Material as a Learning Media for Elementary School Students," vol. 8, no. 3, pp. 249-257, 2018.

[16] R. Von Ammon, C. Emmersberger, F. Springer, and C. Wolff, "Event-driven business process management and its practical application taking the example of DHL," CEUR Workshop Proc., vol. 412, no. August, 2008.

[17] E. Board, E. Editor, S. Editor, and M. Betz, "of Instructional Technology and," Int. J. Instr. Technol. Distance Learn., vol. 8, no. 5, 2011, doi: 2014.10.

[18] S. Ghavifekr and W. A. W. Rosdy, "Teaching and learning with technology: Effectiveness of ICT integration in schools," Int. J. Res. Educ. Sci., vol. 1, no. 2, pp. 175-191, 2015, doi: 10.21890/ijres.23596.

[19] H. Pieterse, M. S. Olivier, and R. P. Van Heerden, "Reference architecture for android applications to support the detection of manipulated evidence," SAIEE Africa Res. J., vol. 107, no. 2, pp. 92-103, 2016, doi: 10.23919/saiee.2016.8531545.

[20] S. Holla and M. M. Katti, "Android Based Mobile Application Development And Its Security," Continuum (N. Y)., vol. 3, no. 3, pp. 486-490, 2012, doi: 10.1080/10304312.2012.706462.

[21] J. Khan and S. Shahzad, "Android Architecture and Related Security Risks," Asian J. Technol. Manag. Res., vol. 05, no. March, pp. 2249-892, 2016.

[22] M. Faheem, N.-A. Le-Khac, and T. Kechadi, "Smartphone Forensic Analysis: A Case Study for Obtaining Root Access of an Android Samsung S3 Device and Analyse the Image without an Expensive Commercial Tool," J. Inf. Secur., vol. 05, no. 03, pp. 83-90, 2014, doi: 10.4236/jis.2014.53009.

[23] Y. Nagm-Aldeen, M. A. Abdel-Fattah, and A. El-Khedr, "A Literature Review of Business Process Modeling Techniques," Int. J. Adv. Res. Comput. Sci. Softw. Eng., vol. 5, no. 3, pp. 43-47, 2015.

[24] T. C. de Sousa, L. Kelvin, C. Dias Neto, and C. Giovanni N. de Carvalho, "A Formal Semantics for Use Case Diagram Via Event-B," J. Softw., vol. 12, no. 4, pp. 189-200, 2017, doi: 10.17706/jsw.12.3.189-200.

[25] M. Touseef, N. Anwer, A. Hussain, and A. Nadeem, "Testing from UML Design using Activity Diagram: A Comparison of Techniques," Int. J. Comput. Appl., vol. 131, no. 5, pp. 41-47, 2015, doi: 10.5120/ijca2015907354.

[26] P. Kamath and V. G. Narendra, "Generation of Test Cases from Behavior Model in UML," Int. J. Appl. Eng. Res., vol. 13, no. 17, pp. 13178-13187, 2018.

[27] M. Sergievskiy, "Description Logic Application for UML Class Diagrams Optimization," Int. J. Adv. Comput. Sci. Appl., vol. 8, no. 1, pp. 268-272, 2017, doi: 10.14569/ijacsa.2017.080134.

[28] S. Ahdan and P. I. Sari, "Pengembangan Aplikasi Web Untuk Simulasi Simpan Pinjam ( Studi Kasus : Bmt L-Risma )," J. TEKNO KOMPAK, vol. 14, no. 1, pp. 33-40, 2020.

[29] S. Ahdan, T. Pambudi, A. Sucipto, and Y. A. Nurhuda, "Game untuk Menstimulasi Kecerdasan Majemuk pada Anak ( Multiple Intelligence) Berbasis Android Game to Stimulate Children 's Multiple Intelligence Based on Android," no. November, pp. 554-568, 2019. 